\title{
In vitro assessment of inter-kingdom biofilm formation by bacteria and filamentous fungi isolated from a drinking water distribution system
}

\author{
Tiago Barros Afonso, Lúcia Chaves Simões and Nelson Lima
}

CEB, Centre of Biological Engineering, University of Minho, Braga, Portugal

ABSTRACT

The main focus so far in the study of biofilm formation in drinking water has been bacteria. Studies on biofilm formation involving filamentous fungi are, therefore, scarce. This study aimed to assess and characterize the ability of these microorganisms to interact with bacteria whilst forming inter-kingdom biofilms. Biofilms were analysed in terms of total biomass, metabolic activity, bacterial colony forming units and morphology by epifluorescence microscopy. The quantitative methods revealed that biofilm mass increased over time for both single and interkingdom biofilms, while specific metabolic activity decreased, in general, along the time points evaluated. Microscopic data visually confirmed the biofilm mass increase over time. This study shows that fungal stage development is important in the first $24 \mathrm{~h}$ of biofilm formation. Interkingdom biofilm formation is microorganism dependent and inter-kingdom biofilms may provide an advantage to the opportunistic bacterium Acinetobacter calcoaceticus to replicate and proliferate when compared with Methylobacterium oryzae.
ARTICLE HISTORY

Received 15 June 2019

Accepted 29 October 2019

\section{KEYWORDS}

Penicillium expansum; Penicillium brevicompactum; bacteria; biomass quantification; microtitre plates; microscopy

\section{Introduction}

Biofilms can be considered the main source of microorganisms in drinking water distribution systems (DWDS), and may contribute to the deterioration of drinking water (DW) quality (Momba et al. 2000; Berry et al. 2006). The presence of biofilms in DWDS can have serious effects, including changes in the turbidity, taste, odour and colour of the water, an increase in cell numbers in the bulk phase, biocorrosion, decay of residual disinfectant, increased habitat for pathogens, and production of toxins (Paterson and Lima 2005; Feazel et al. 2009; Li et al. 2015; Wang et al. 2017; Zhou et al. 2017). The study of biofilms in DWDS has mainly focused on bacteria as they are generally the dominant microorganisms, due to their high growth rates, small size, ability to produce extracellular polymeric substances (EPS) and high adaptation capacities (Characklis and Marshall 1990). The ecology of a biofilm depends on a complex mix of prevailing growth conditions, hydrodynamic forces, presence of microbial metabolites and molecules excreted by dominant microbial habitants of the biofilm (Bryers and Ratner 2004). Despite DWDS being considered 'unnatural' habitats to filamentous fungi, they can often be introduced into these environments from different locations (e.g. physical openings in storage facilities, leaking joints and adapters and cracks in pipelines) and cause additional problems such as unpleasant appearance, pigments, blocked pipes, a source of potentially pathogenic and allergy-causing fungi and the production of mycotoxins (Metzger et al. 1976; Åslund 1984; Paterson and Lima 2005, 2010; Gonçalves et al. 2006; Hageskal et al. 2007). Studies considering fungi as pathogenic microorganisms in DWDS are sparse when compared to bacteria, mainly because water contaminated by fungi does not lead to acute disease (Hageskal et al. 2009). While the term 'biofilm' has been rarely applied to filamentous fungi, there have been indications that they grow as biofilms in diverse environmental, medical and industrial settings (Anaissie et al. 2003; Gutierrez-Correa and Villena 2003; Mowat et al. 2007; Siqueira et al. 2013; Simões et al. 2015). This is due to their ability to grow on surfaces, as shown by their absorptive nutrition mode, secretion of extracellular enzymes to digest complex molecules, and apical hyphal growth (Jones 1994). Few reports on filamentous fungal biofilms in DWDS can be found in the literature; however, there are already indepth studies of filamentous fungal biofilms in other environments, especially regarding the fungal pathogen

CONTACT Nelson Lima nelson@ie.uminho.pt

(-) Supplemental material for this paper is available online at http://dx.doi10.1080/08927014.2019.1688793.

(C) 2019 Informa UK Limited, trading as Taylor \& Francis Group 
Aspergillus fumigatus (Muller et al. 2001; Ramage et al. 2011; Siqueira et al. 2011, 2013; Simões et al. 2015; González-Ramírez et al. 2016; Sav et al. 2018). Harding et al. (2009) proposed a six-step preliminary model for biofilm formation by filamentous fungi based on previously published descriptions of such biofilms and drawing from bacterial and yeast models: propagule adsorption, active attachment to a surface, microcolony formation I, microcolony formation II or initial maturation, maturation or reproductive development, and a dispersal or planktonic phase. Simões et al. (2015) demonstrated that similar to bacterial biofilms, it was possible to identify these same phases in biofilm formation by filamentous fungi. Filamentous fungi are, therefore, excellent candidates for biofilm formation.

Under natural conditions, true monospecies biofilms are rare, and biofilms are usually considered as complex communities (Douterelo et al. 2018). This diversity leads to a variety of complex relationships involving interspecies and intraspecies interactions (Douterelo et al. 2016). Although intraspecies interactions may play an important role in the coexistence of some microbiomes, biotic interactions between distantly related organisms across the kingdoms of life can also regulate the composition of these communities (Kastman et al. 2016). In many microbiomes, bacteria can coexist with different eukaryotic microorganisms, including fungi (Frey-Klett et al. 2011). One type of such interactions can occur in biofilms. As the microorganisms are closely embedded in an extracellular matrix, interkingdom biofilms containing bacteria and fungi (both nonfilamentous and filamentous) can be considered a more close level of bacterial-fungal interaction but this aspect is still poorly understood (Frey-Klett et al. 2011). In these mixed biofilms both organisms can exist as dual complexes or fungi may offer biotic support for the establishment of a bacterial biofilm (Seneviratne et al. 2008; Lahaye et al. 2016). Understanding the mechanisms of interaction between these organisms is fundamental to unravel the kinetics of inter-kingdom biofilm formation.

As there is a gap in the study of inter-kingdom biofilms between bacteria and filamentous fungi found in DWDS, the purpose of this work was to assess the ability of these microorganisms to interact with each other in biofilm formation.

\section{Materials and methods}

\section{Microorganisms and culture conditions}

Penicillium expansum MUM 00.02 and Penicillium brevicompactum MUM 05.17, supplied by Micoteca da Universidade do Minho fungal culture collection (MUM, Braga, Portugal), were chosen based on their high occurrence in the tap water in the north of Portugal (Gonçalves et al. 2006). P. expansum and $P$. brevicompactum were maintained on malt extract agar (MEA: malt extract $20 \mathrm{~g}$, peptone $5 \mathrm{~g}$, agar $20 \mathrm{~g}$, distilled water 11 ).

Acinetobacter calcoaceticus and Methylobacterium oryzae were previously isolated from model laboratory DWDS by Simões et al. (2007b). They were chosen for being representative of drinking water bacteria and due to their ability to form complex biofilms (Simões et al. 2010). A. calcoaceticus was grown overnight while $M$. oryzae was grown for $72 \mathrm{~h}$ before the start of the assay. The bacteria were grown in batch cultures using $100 \mathrm{ml}$ of $\mathrm{R} 2 \mathrm{~A}$ broth (yeast extract $0.5 \mathrm{~g}$, proteose peptone $0.5 \mathrm{~g}$, casein hydrolysate $0.5 \mathrm{~g}$, glucose $0.5 \mathrm{~g}$, soluble starch $0.5 \mathrm{~g}$, dipotassium phosphate $0.3 \mathrm{~g}$, magnesium sulphate $0.024 \mathrm{~g}$, sodium pyruvate $0.3 \mathrm{~g}$, distilled water $1 \mathrm{l}$ ) at room temperature $\left(25 \pm 2{ }^{\circ} \mathrm{C}\right)$ and under agitation $(150 \mathrm{rpm})$. Afterwards, the bacterial cells were harvested by centrifugation (10 min at 13,000 $\times g$, room temperature), washed three times in $0.1 \mathrm{M}$ saline phosphate buffer, and resuspended in a volume of $\mathrm{R} 2 \mathrm{~A}$ to obtain a cellular density of $1 \times 10^{8}$ cells $\mathrm{ml}^{-1}$. This was the bacterial concentration used for biofilm formation assays.

\section{Stock solution of fungal spores}

Stock solutions of fungal spores were prepared according to Simões et al. (2015). Briefly, spores of $P$. expansum and $P$. brevicompactum were harvested from seven-day-old pure cultures in MEA at $25^{\circ} \mathrm{C}$ by flooding the surface of the agar plates with $2 \mathrm{ml}$ of TWS solution $(0.85 \% \mathrm{NaCl}$ plus $0.05 \%$ Tween 80$)$ and rocking gently. The suspension was then homogenized by vortexing and used for large-scale production of spores. The final spore suspension was homogenized by vortexing before quantification using a Neubauer count chamber. Several aliquots of spore suspension with $10 \%$ of glycerol were cryopreserved at $-80^{\circ} \mathrm{C}$ in order to allow the use of the same spore suspension in all the biofilm assays. Stock spore suspensions were resuspended in the volume of R2A broth necessary to achieve a density of $10^{5}$ spores $\mathrm{ml}^{-1}$. This was the spore concentration used for biofilm formation assays. Assays were performed using fresh fungal spores or germinated fungal spores. Spores were pre-germinated in order to stimulate their metabolic state. Germinated fungal spores were prepared by inoculating $10^{5}$ fresh spores $\mathrm{ml}^{-1}$ in $\mathrm{R} 2 \mathrm{~A}$ 
broth for $\sim 14 \mathrm{~h}$ (sufficient time for $>95 \%$ of the spores to have germinated).

\section{Biofilm formation}

Biofilms were developed according to the modified microtitre plate test used by Stepanović et al. (2000) for bacteria and Simões et al. (2015) for fungi. Briefly, 16 wells of sterile polystyrene 96-well flat-bottomed culture plates (Greiner Bio-One Cellstar ${ }^{\circledR}$, Kremsmünter, Austria) were filled under aseptic conditions with $200 \mu \mathrm{l}$ of spore suspension $\left(10^{5}\right.$ spores $\mathrm{ml}^{-1}$ in R2A broth) or $200 \mu \mathrm{l}$ of a cell suspension $\left(10^{8}\right.$ cell $\mathrm{ml}^{-1}$ in $\mathrm{R} 2 \mathrm{~A}$ broth) for the single-species biofilms, which were also used as positive controls. For inter-kingdom biofilm formation, $100 \mu$ of fresh fungal spore suspension or germinated fungal spore suspension and $100 \mu \mathrm{l}$ of the bacterial cell suspension was added to each well. The reduction to half cell density in the inter-kingdom assays was performed to avoid limitation in nutritional factors. Each fungal species grew alongside each bacterium. To promote biofilm formation, all plates were incubated aerobically at room temperature $\left(25 \pm 2{ }^{\circ} \mathrm{C}\right)$ and under agitation $(150 \mathrm{rpm})$ for 24,48 and $72 \mathrm{~h}$. The medium was renewed each $24 \mathrm{~h}$. At each sampling time, the content of each well was removed and washed twice with $200 \mu \mathrm{l}$ of sterile distilled water to remove non-adherent and weakly adherent cells. The plates were air dried for $30 \mathrm{~min}$ to remove excess water by evaporation. The remaining attached cells were analysed in terms of biomass adhered on the inner walls of the wells, and in terms of metabolic activity and colony forming units (CFU) for bacteria. The rinsing and drying procedures were as previously used with bacterial and fungal biofilms (Simões et al. 2007a, 2010, 2015). The morphology of inter-kingdom biofilms was also qualitatively characterized by epifluorescence microscopy. Negative controls were obtained by incubating the wells with only R2A broth without adding any fungal spores or bacterial cells. Experiments were performed in triplicate with at least three repeats.

\section{Biofilm monitoring by spectrophotometric methods}

\section{Biofilm mass quantification by crystal violet}

The biomass adhered on the inner walls of the wells was quantified by the crystal violet (CV) method according to the procedure described by Stepanović et al. (2000). The fungal biofilms in the 96-well plates were fixed with $200 \mu \mathrm{l} \mathrm{well}{ }^{-1}$ of $98 \%$ methanol
(VWR, Carnaxide, Portugal) for $15 \mathrm{~min}$. Afterwards, the methanol was discarded, the plates left to dry and then the fixed biofilm was stained with $200 \mu \mathrm{l} \mathrm{well}^{-1}$ of CV (Merck, Darmstadt, Germany) for $5 \mathrm{~min}$. Excess stain was rinsed out by placing the plate under slow running tap water. After this, the plates were air dried and the dye bound to the adherent cells was resolubilized by adding $200 \mu \mathrm{l} \mathrm{well}{ }^{-1}$ of $33 \%\left(\mathrm{v} \mathrm{v}^{-1}\right)$ glacial acetic acid (Panreac, Cascais, Portugal). The optical density of the solution obtained was measured at $570 \mathrm{~nm}$ using a microtitre plate reader (BioTek, Winooski, VT, USA) and the fungal biofilm mass was presented as $\mathrm{OD}_{570 \mathrm{~nm}}$ values.

\section{Biofilm metabolic activity assessment by resazurin}

Resazurin (7-hydroxy-3H-phenoxazin-3-one-10-oxide) (Sigma-Aldrich, St. Louis, MO, USA) is a viability dye used to assess the metabolic activity of biofilms (Borges et al. 2012). For each biofilm growth period, fresh R2A broth $(190 \mu \mathrm{l})$ was added to the plates. A volume of $10 \mu \mathrm{l}$ of resazurin $(400 \mu \mathrm{M})$ indicator solution was added to each well, in order to obtain a final resazurin concentration of $20 \mu \mathrm{M}$. Plates were incubated in the dark for $3 \mathrm{~h}$ at $25^{\circ} \mathrm{C}$. The staining protocol was optimized for inter-kingdom biofilms containing fungi and bacteria, in terms of time and temperature of incubation (data not shown). Fluorescence was measured after excitation at $530 \mathrm{~nm}$ and emission at $590 \mathrm{~nm}$ using a microtitre plate reader (BioTek). The biofilm specific metabolic activity was expressed as fluorescence/ $\mathrm{OD}_{570 \mathrm{~nm}}$ (biofilm metabolic activity/biofilm mass).

\section{Number of bacteria in single and inter- kingdom biofilms}

The number of bacterial cells present in either A. calcoaceticus or $M$. oryzae single species biofilms and in inter-kingdom biofilms was determined in terms of CFU using a plate count assay upon biofilm release. Briefly, bacterial single-species biofilms and interkingdom biofilms were grown in a 96-well plate as previously described. After each incubation period, the supernatant was removed, and the plate was washed three times with sterile water. A volume of $200 \mu \mathrm{l}$ of sterile phosphate buffer saline ( $\mathrm{pH}$ 7.4) was added into each well and the 96-well plate was covered with the lid and placed into an ultrasonic bath (Bandelin electronic GmbH \& Co. KG, Berlin, Germany). To release bacterial cells from biofilm, the 96-well plate was sonicated for $1 \mathrm{~min}$ ( $5 \mathrm{~s}$ sonicate, $10 \mathrm{~s}$ interval) at $35 \mathrm{kHz}$. Three replicates were used for 
each sample and bacterial cells were plated onto R2A agar plates for CFU determination.

\section{Biofilm monitoring by epifluorescence microscopy}

At each sampling time, a coupon of polystyrene $\left(1 \mathrm{~cm}^{2}\right)$ that had been inserted in a 24-well microtitre plate was inspected by an Olympus BX51 epifluorescence microscope (Olympus, Tokyo, Japan) with different stains: calcofluor white M2R (CW) (Invitrogen/ Molecular Probes, Leiden, the Netherlands) to stain the fungi and 4,6-diamino-2-phenylindole (DAPI) (Sigma-Aldrich) to stain the bacteria. Washed fungal biofilms were stained with $10 \mu \mathrm{l}$ of $25 \mu \mathrm{M} \mathrm{CW}$ at room temperature for $15 \mathrm{~min}$, in the dark. Washed bacterial biofilms were stained with $10 \mu \mathrm{l}$ of $100 \mu \mathrm{g}$ $\mathrm{ml}^{-1}$ DAPI at room temperature for $15 \mathrm{~min}$, in the dark. Washed inter-kingdom biofilms were stained with $5 \mu \mathrm{l}$ of $25 \mu \mathrm{M} \mathrm{CW}$ and $5 \mu \mathrm{l}$ of $100 \mu \mathrm{g} \mathrm{ml}^{-1}$ DAPI at room temperature for $15 \mathrm{~min}$ in the dark. After staining, biofilm samples were observed under epifluorescence microscopy. The optical filter combination used for CW and DAPI were a $365-370 \mathrm{~nm}$ excitation filter, a LP421 nm emission filter and a $400 \mathrm{~nm}$ barrier filter. Biofilms images were acquired with a microscope camera (Olympus DP71) using the cellSens software (Olympus Corporation).

\section{Statistical analysis}

The data were analysed using the software GraphPad Prism version 8.0.2 (GraphPad Software, La Jolla, CA, USA). The mean and standard deviation (SD) within samples were calculated for all cases. The statistical significance of results was determined by unpaired $t$ test. $p<0.05$ was considered to be statistically significant.

\section{Results}

Biofilm mass quantification and specific metabolic activity of biofilms

In order to assess biofilm formation and the specific metabolic activities of the selected single-species (used as controls) and inter-kingdom biofilms, the standard 96-well microtitre plates with $\mathrm{CV}$ and resazurin were used. The results for biofilm mass quantification are presented in Figure 1, while the results for specific metabolic activity are presented in Figure 2. Statistical analysis is shown in Figures S1 and S2 (Supplemental material). The results are divided for $P$. expansum (Figures $1 \mathrm{a}$ and $2 \mathrm{a}$ ) and $P$. brevicompactum (Figures
$1 \mathrm{~b}$ and $2 \mathrm{~b}$ ). The biofilm mass results revealed an increase over time for all single-species (bacteria and fungi) and inter-kingdom biofilms combinations $(p<0.05)$, except for $P$. brevicompactum spores $+M$. oryzae $(p>0.05)$. Fungal species using germinated spores resulted in a higher biofilm mass yield when compared to fresh spores for the first $48 \mathrm{~h}(p<0.05)$. At $72 \mathrm{~h}$ this difference was no longer observed. Interkingdom biofilm formation between $P$. expansum spores $+A$. calcoaceticus revealed significant differences compared to single-species biofilms containing $P$. expansum spores for all time points $(p<0.05)$, while there was only a difference at $72 \mathrm{~h}$ when compared with A. calcoaceticus single-species biofilms (Figure 1a). This displays an inhibitory effect of the bacteria towards $P$. expansum spores. When P. expansum germinated spores were present, this inhibitory effect was still significant at $24 \mathrm{~h}$, less prominent at $48 \mathrm{~h}(p<0.05)$ and null at $72 \mathrm{~h}(p>0.05)$. Biofilm formation between $P$. expansum spores $+M$. oryzae revealed significant differences when compared with single-species biofilms of $P$. expansum spores for all time points $(p<0.05)$, while there was a difference at 48 and $72 \mathrm{~h}$ when compared with $M$. oryzae singlespecies biofilms (Figure 1a). This also demonstrates an inhibitory effect of this bacterium towards $P$. expansum spore germination. When germinated spores were present, this effect was less pronounced $(p<0.05)$, similarly to inter-kingdom biofilms with $A$. calcoaceticus. Inter-kingdom biofilm formation between $P$. brevicompactum spores and germinated spores with both bacteria followed the same pattern of inhibition as $P$. expansum spores and germinated spores $(p<0.05)$ (Figure 1b).

Figure 2 shows the results obtained for the specific metabolic activity of $P$. expansum (Figure 2a) and $P$. brevicompactum (Figure $2 \mathrm{~b}$ ) biofilms. The specific metabolic activity (per biomass) increased in singlespecies biofilms containing $P$. expansum spores from 24 to $48 \mathrm{~h}$ and then decreased at $72 \mathrm{~h}(p<0.05)$. Using germinated spores, the specific metabolic activity of $P$. expansum increased at $24 \mathrm{~h}$ relative to the use of fresh spores. The metabolic activity of biofilms with germinated spores of $P$. expansum was at its highest at $24 \mathrm{~h}$ and then decreased over time $(p<0.05)$. This loss in specific metabolic activity per biomass was also found in A. calcoaceticus single-species biofilms. This bacterium had the highest values for metabolic activity registered in this study. For this reason, in inter-kingdom biofilms containing of $A$. calcoaceticus, the data for metabolic activity were compared with A. calcoaceticus single-species biofilms 

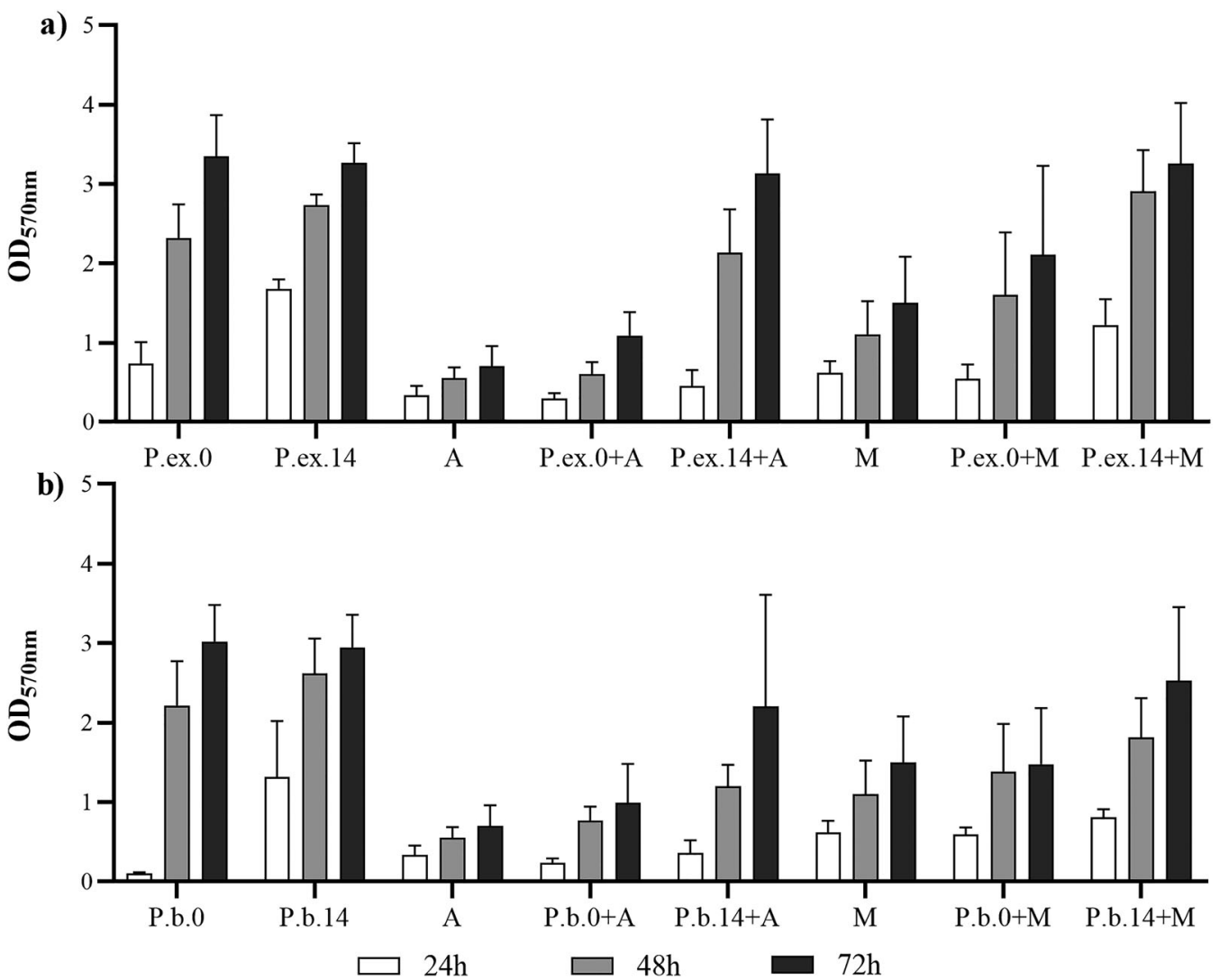

Figure 1. Biofilm mass quantification for single-species and inter-kingdom biofilm formation over time with (a) $P$. expansum or (b) P. brevicompactum. Abbreviations: P.ex.0, P. expansum spores; P.ex.14, P. expansum germinated spores at $14 \mathrm{~h} ; \mathrm{A}, A$. calcoaceticus; M, M. oryzae; P.b.0, P. brevicompactum spores; P.b.14, P. brevicompactum germinated spores at $14 \mathrm{~h}$. The means \pm SDs for three independent experiments are illustrated.

as it surpassed the metabolic activity of the fungi. In $P$. expansum spores $+A$. calcoaceticus biofilms, metabolic activity was maintained for the first $48 \mathrm{~h}$ $(p>0.05)$ while there was a decrease at $72 \mathrm{~h}$ $(p<0.05)$. When germinated spores of $P$. expansum were present with $A$. calcoaceticus, there was no change in the metabolic activity of the biofilm at $24 \mathrm{~h}$, but a decrease was observed at 48 and $72 \mathrm{~h}(p<0.05)$.

The specific metabolic activity related to $M$. oryzae single-species biofilms showed a decrease from 24 to $48 \mathrm{~h}(p<0.05)$ and then it was maintained between 48 and $72 \mathrm{~h}(p>0.05)$. In inter-kingdom biofilm formation of $P$. expansum spores $+M$. oryzae metabolic activity was maintained at $24 \mathrm{~h}$ when compared with the single-species biofilms of both microorganisms, a decrease at $48 \mathrm{~h}$ when compared with $P$. expansum spores single-species biofilm and an increase at $72 \mathrm{~h}$ when compared with both microorganisms single-species biofilms $(p<0.05)$. In the presence of germinated spores of $P$. expansum activity was maintained at $24 \mathrm{~h}$ compared to $P$. expansum germinated spores singlespecies biofilm and then there was a slight decrease at 48 and $72 \mathrm{~h}(p<0.05)$.
Analysis of the results with $P$. brevicompactum revealed that specific metabolic activity was maintained for the duration of the experiments when using fungal spores or germinated spores $(p>0.05)$ (Figure $2 b)$. In the presence of $A$. calcoaceticus, the same surpassing effect was observed due to the difference in the metabolic activities of the microorganisms. In $P$. brevicompactum spores $+A$. calcoaceticus biofilms, metabolic activity was higher at $24 \mathrm{~h}$ compared with $A$. calcoaceticus single-species biofilms and then a decrease was observed at 48 and $72 \mathrm{~h}(p<0.05)$. With germinated spores of $P$. brevicompactum the increase in metabolic activity at $24 \mathrm{~h}$ was not observed $(p>0.05)$, but the decrease at 48 and $72 \mathrm{~h}$ was more pronounced $(p<0.05)$. In inter-kingdom biofilms containing $P$. brevicompactum spores $+M$. oryzae there was a decrease in metabolic activity for all time points when compared with $M$. oryzae single-species biofilms $(p<0.05)$. For $P$. brevicompactum germinated spores $+M$. oryzae biofilms, metabolic activity was maintained for the first $48 \mathrm{~h}$ compared with $M$. oryzae single species biofilms, but an increase was observed at $72 \mathrm{~h}(p<0.05)$. 

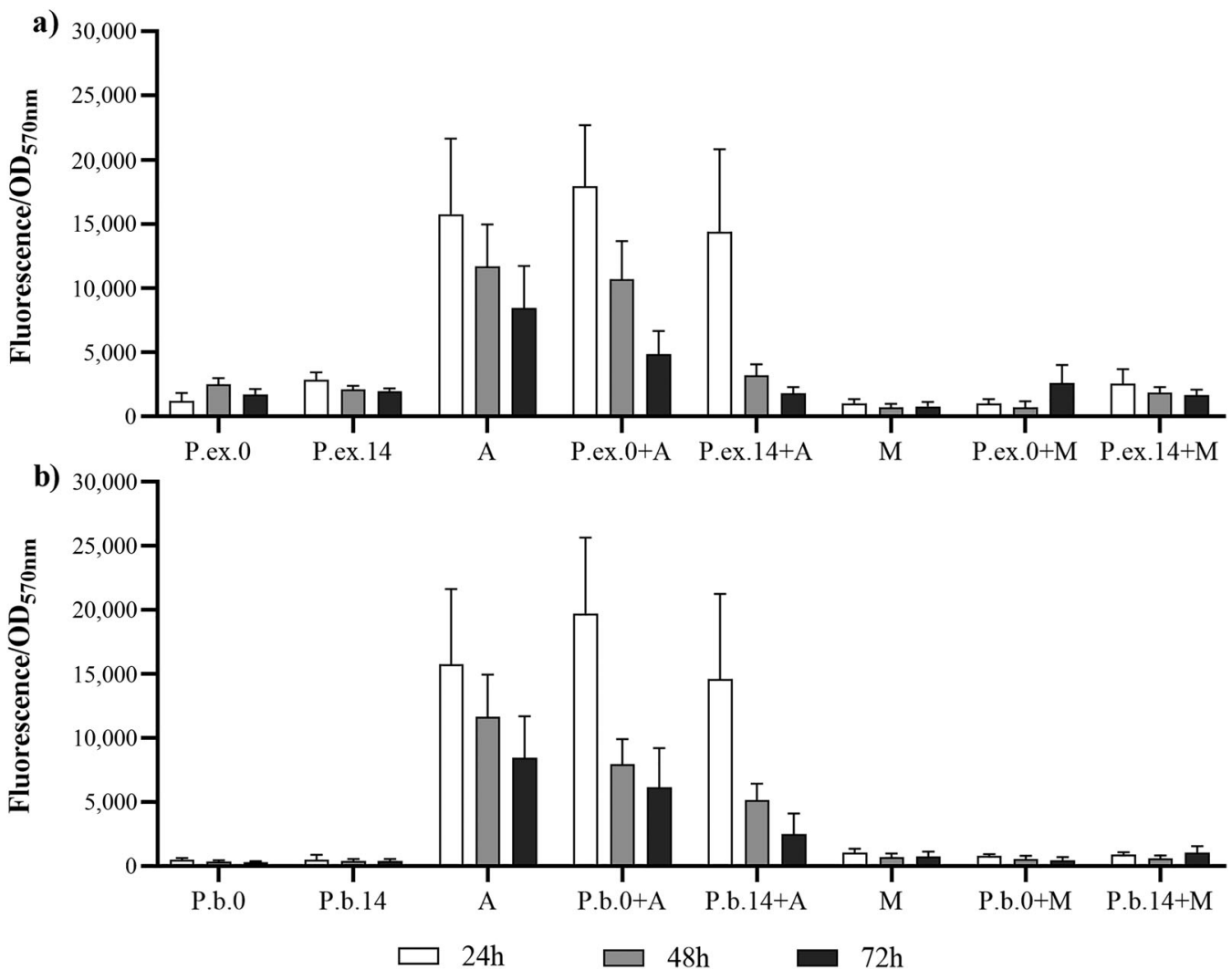

Figure 2. Specific metabolic activity for single-species and inter-kingdom biofilm formation over time with (a) $P$. expansum or (b) P. brevicompactum. Abbreviations: P.ex.0, P. expansum spores; P.ex.14, P. expansum germinated spores at $14 \mathrm{~h} ; \mathrm{A}, \mathrm{A}$. calcoaceticus; M, M. oryzae; P.b.0, P. brevicompactum spores; P.b.14, P. brevicompactum germinated spores at $14 \mathrm{~h}$. The means \pm SDs for three independent experiments are illustrated.

\section{Cell density in single-species and inter- kingdom biofilms}

The numbers of bacterial cells present in both singlespecies biofilms and in inter-kingdom biofilms was determined as CFU and the results are presented in Figure 3. Statistical analysis is shown in Figure S3 (Supplemental material). Bacterial single-species biofilms were used as controls. Analysing A. calcoaceticus results (Figure 3a), an increase in $\mathrm{CFU}$ at $24 \mathrm{~h}$ was observed for A. calcoaceticus $+P$. expansum germinated spores and $A$. calcoaceticus $+P$. brevicompactum spores $(p<0.05)$. At $48 \mathrm{~h}$, compared with $A$. calcoaceticus single-species biofilms, an increase in CFU for this bacterium was observed $(p<0.05)$ for all inter-kingdom biofilms, except for A. calcoaceticus $+P$. brevicompactum germinated spores $(p>0.05)$. At $72 \mathrm{~h}$, there was an increase in CFU when this bacterium grew alongside $P$. expansum spores or germinated spores $(p<0.05)$. No significant changes were observed for inter-kingdom biofilm formation with $P$. brevicompactum spores, but with $P$. brevicompactum germinated spores, an increase in CFU was observed. With $P$. expansum germinated spores, the number of
CFU was higher when compared with fresh spores for all sampling times $(p<0.05)$.

Regarding $M$. oryzae results (Figure $3 \mathrm{~b}$ ) a decrease in bacterial CFU was seen at $24 \mathrm{~h}$ when forming inter-kingdom biofilms with fresh spores of both fungi, while there was an increase with $P$. expansum germinated spores and no significant changes with $P$. brevicompactum germinated spores. At $48 \mathrm{~h}$ there was only a decrease with $P$. expansum spores, while for the other conditions the CFU was maintained $(p>0.05)$. At $72 \mathrm{~h}$ a decrease in M. oryzae CFU was detected in inter-kingdom biofilm formation with germinated spores of $P$. expansum, while no significant changes were observed for the remaining conditions.

\section{Microscopic visualization of biofilms}

Biofilms were also qualitatively characterized by epifluorescence microscopy. The results are presented in Figure 4 for the presence of A. calcoaceticus and in Figure 5 for the presence of $M$. oryzae. Higher magnification images are shown in Figures S4 and 

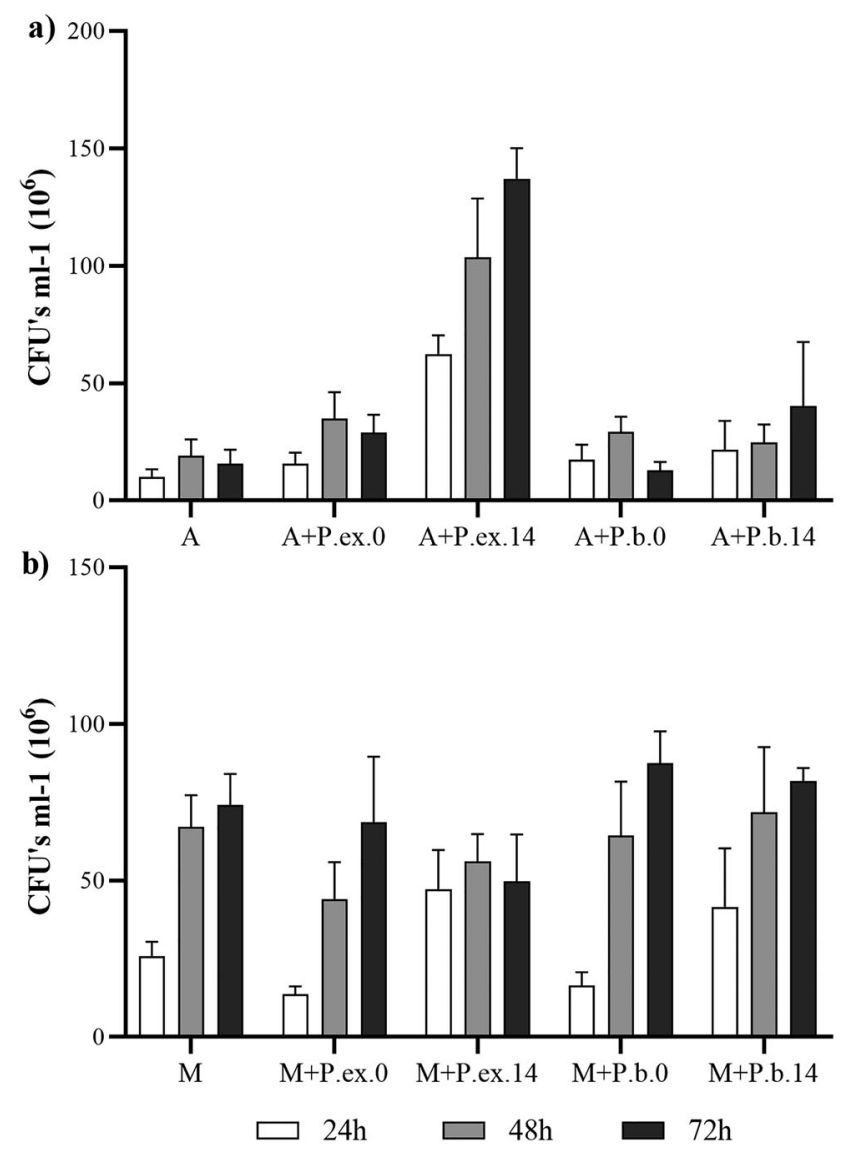

Figure 3. CFU counts for (a) A. calcoaceticus or (b) M. oryzae while forming single-species or inter-kingdom biofilm formation over time. Abbreviations: $\mathrm{A}, \mathrm{A}$. calcoaceticus; $\mathrm{M}, \mathrm{M}$. oryzae; P.ex.0, $P$. expansum spores; P.ex.14, $P$. expansum germinated spores at 14 h; P.b.0, P. brevicompactum spores; P.b.14, P. brevicompactum germinated spores at $14 \mathrm{~h}$. The means \pm SDs for two independent experiments are illustrated.

S5 (Supplemental material) respectively. Microscopic data visually confirmed the biofilm mass increase over time. The differences in inoculating $P$. expansum spores or germinated spores with A. calcoaceticus (Figure $4 \mathrm{a}, \mathrm{b}$ and $\mathrm{c}$ ) or M. oryzae (Figure $5 \mathrm{a}, \mathrm{b}$ and c) was noticeable at $24 \mathrm{~h}$ with a visual increase in fungal density. At $24 \mathrm{~h}$ it was not possible to detect fungal mass for $P$. brevicompactum spores + A. calcoaceticus nor $P$. brevicompactum germinated spores $+A$. calcoaceticus. With higher magnification it was possible to detect bacterial cells growing around the fungal hyphae. It was also possible to see that bacteria were the primary colonizers, as they formed the first biofilm layer (they are usually on a lower focal point). However, due to the increase in fungal mass over time, bacterial cells became harder to detect, and in some cases, their detection was not achieved. For this reason, images of $72 \mathrm{~h}$ biofilms were not included.

\section{Discussion}

Microbial growth and biofilm formation are dependent on a variety of factors, both biological and physico-chemical. DW biofilms are formed of a complex microbial community of very different organisms (bacteria, fungi, protozoa, viruses and algae) but all adapted to grow under oligotrophic conditions and in the presence of a disinfectant (Gonçalves et al. 2006; Simões et al. 2008, 2010; Siqueira et al. 2011). Studies on the microbial ecology of DWDS have shown that the resistance of microorganisms to disinfectants, particularly chlorine, is affected by this microbial diversity and interspecies interactions (Berry et al. 2006; Simões et al. 2010). This information was, however, largely obtained from studies with bacteria. Very few reports have been published on filamentous fungal biofilms (Siqueira et al. 2011; Simões et al. 2015; Fernandes et al. 2019). The influence of these organisms in DW biofilms, particularly in their interaction with bacteria, is still poorly understood.

Since DWDS are very complex systems, of difficult accessibility, biofilm studies in situ are not common (Douterelo et al. 2014, 2018). In order to study DW biofilms separately from DWDS several devices and methodologies have been developed (Gomes et al. 2014). Microtitre plates are the most frequently used in vitro model for studying biofilm formation under strict laboratory conditions, including with DW microorganisms (Gomes et al. 2014). Despite the disadvantages they have in the reproducing conditions found in DWDS (i.e. hydrodynamic forces), polystyrene microtitre plates are commonly used as the standard bioreactor system to study adhesion and biofilm formation by bacteria and fungi isolated from these systems (Simões et al. 2010, 2015; Gomes et al. 2014). They can be used as a rapid and simple method for analysing the effects of a variety of parameters on biofilm formation as equivalent biofilms can be produced simultaneously (Simões et al. 2007a, 2010, 2015). Polystyrene also has physico-chemical surface properties similar to those of other materials used in DWDS, such as polyvinylchloride and stainless steel (Simões et al. 2007b). Regions of low shear stress easily reproduced by microtitre plates are common in DWDS, particularly in reservoirs, households pipes, corners and valves. These areas are associated with zones of abundant biofilm formation due to the high accumulation of organic material (Simões and Simões 2013). For the reasons depicted, microtitre plates were selected to study biofilm formation and behaviour of inter-kingdom biofilms containing fungi and bacteria isolated from DW. 
a)

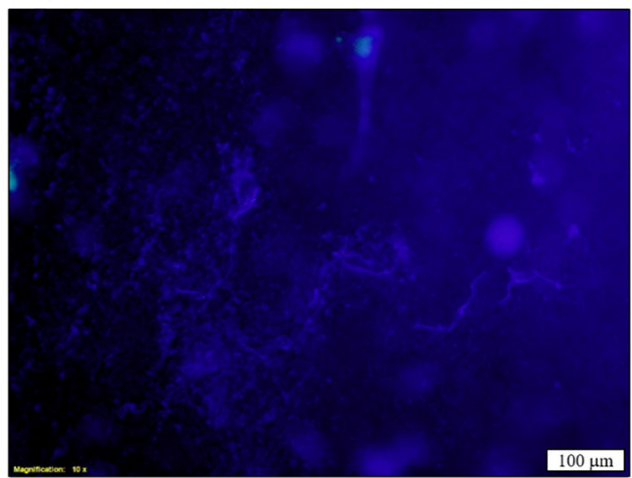

c)

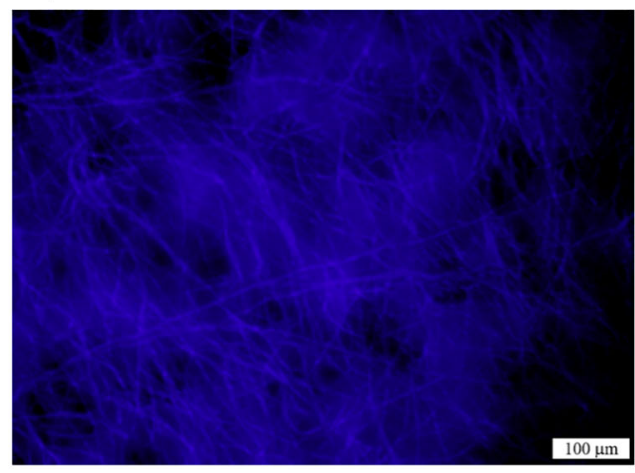

e)

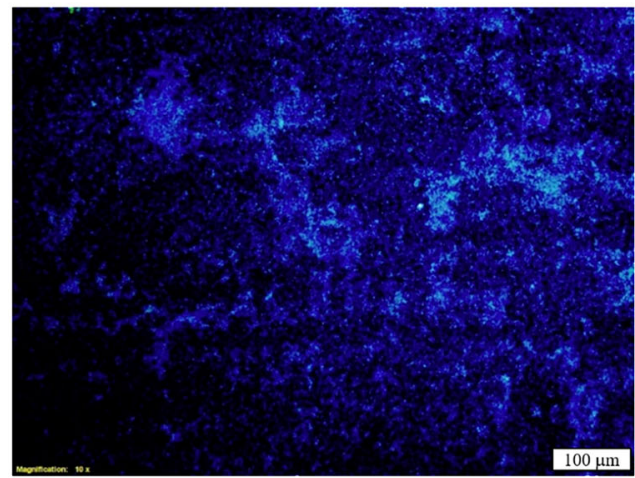

g)

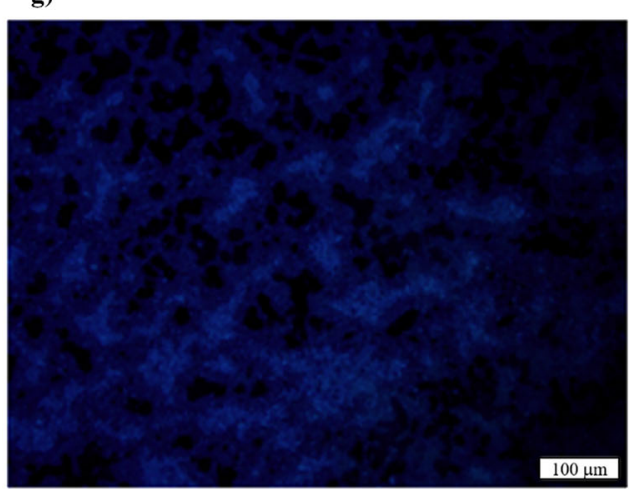

b)

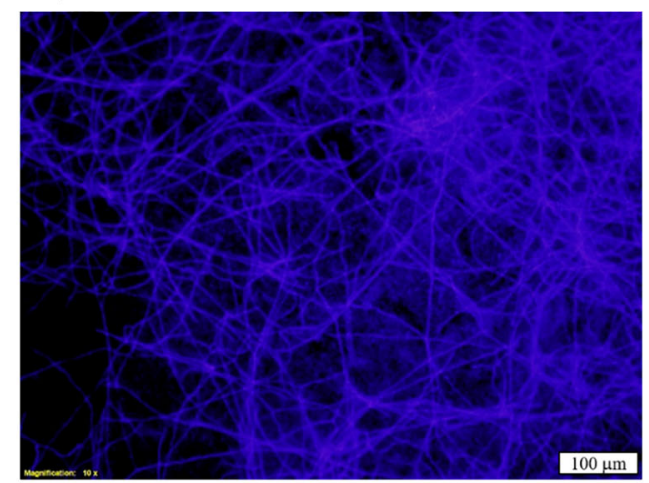

d)

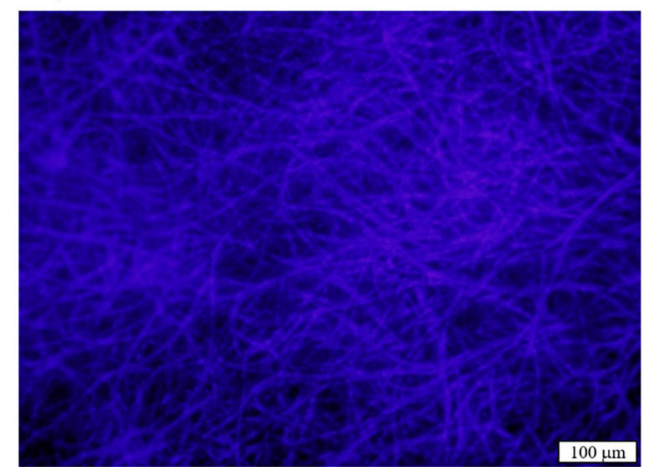

f)

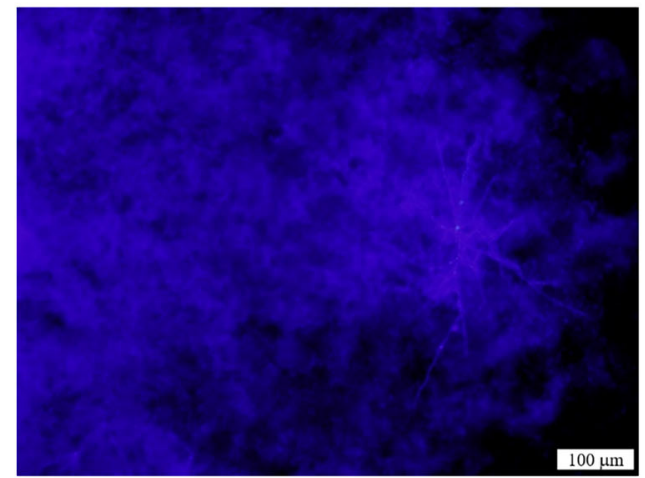

h)

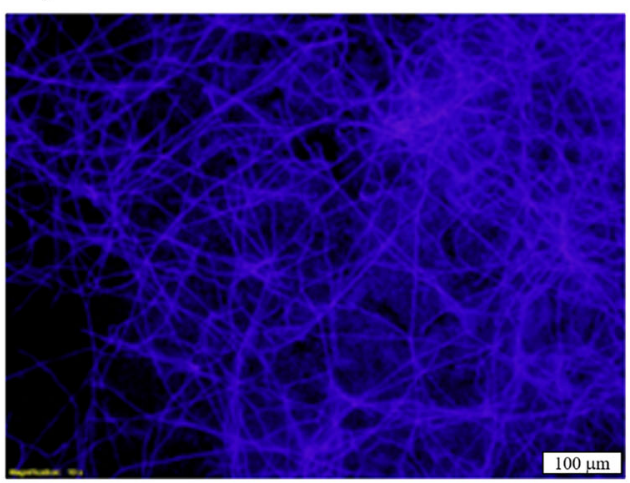

Figure 4. Epifluorescence photomicrographs of inter-kingdom biofilm formation with $A$. calcoaceticus on polystyrene over time with CW plus DAPI: (a) A. calcoaceticus $+P$. expansum spores at $24 \mathrm{~h}$; (b) $A$. calcoaceticus $+P$. expansum spores at $48 \mathrm{~h}$; (c) $A$. calcoaceticus $+P$. expansum germinated spores at $24 \mathrm{~h}$; (d) $A$. calcoaceticus $+P$. expansum germinated spores at $48 \mathrm{~h}$; (e) $A$. calcoaceticus $+P$. brevicompactum spores at $24 \mathrm{~h}$; (f) A. calcoaceticus $+P$. brevicompactum spores at $48 \mathrm{~h}$; (g) $A$. calcoaceticus $+P$. brevicompactum germinated spores at $24 \mathrm{~h}$; (h) A. calcoaceticus $+P$. brevicompactum germinated spores at $48 \mathrm{~h}$. $\times 200 \mathrm{magnifica-}$ tion; bars $=100 \mu \mathrm{m}$. 
a)

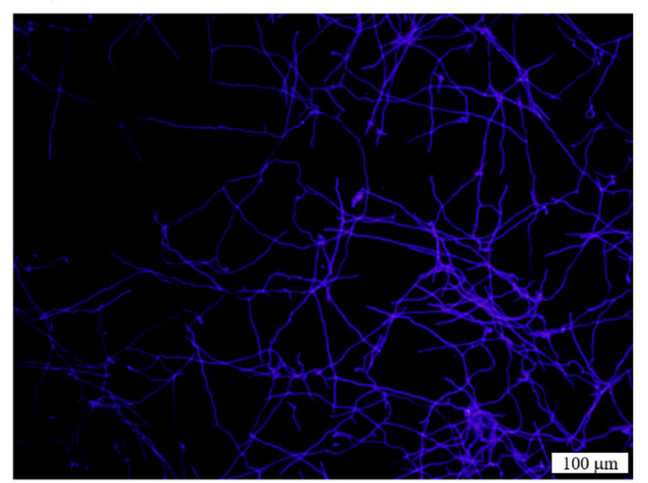

c)

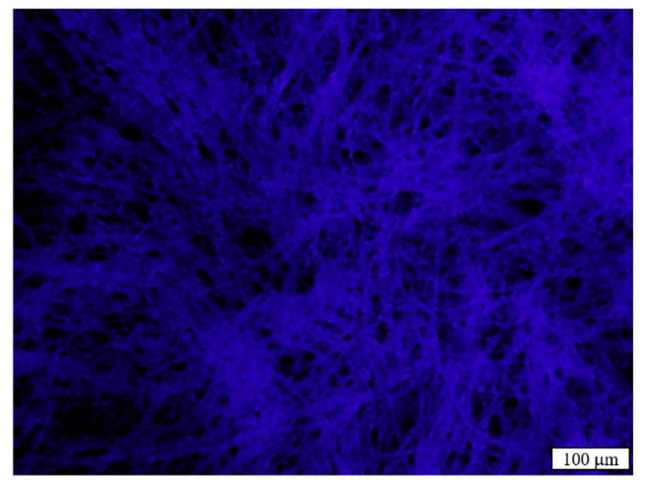

e)

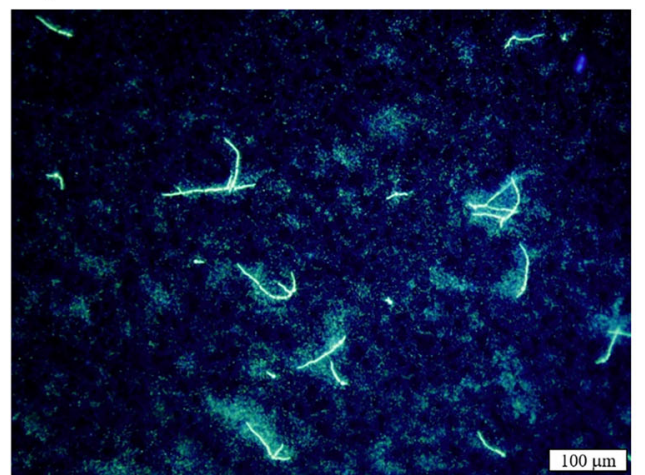

g)

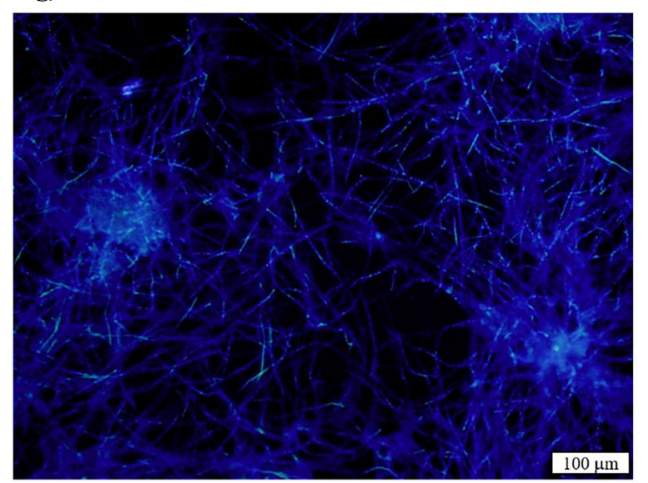

b)

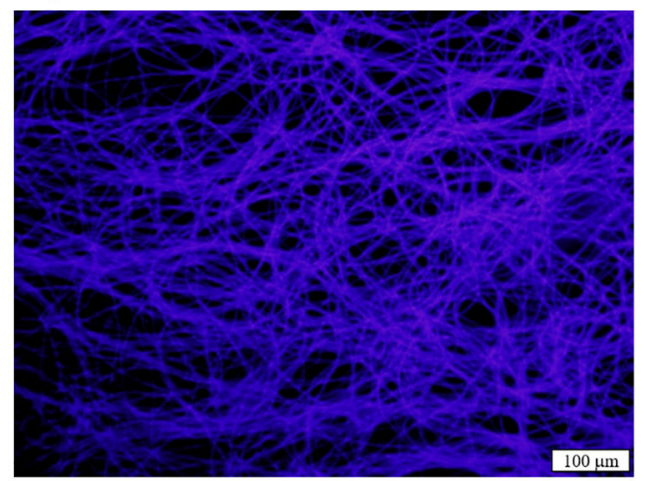

d)

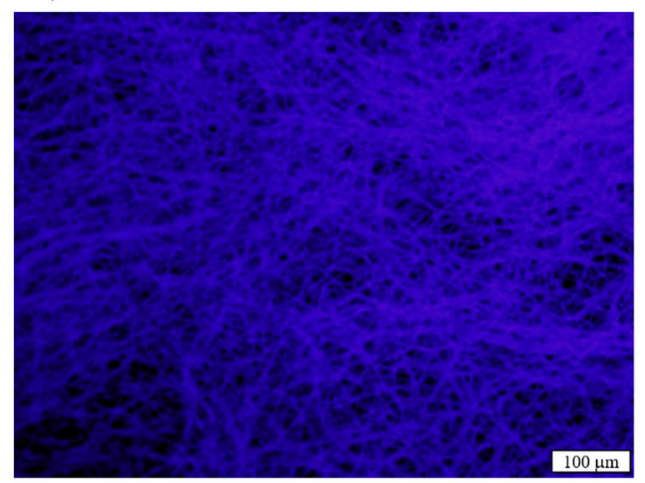

f)

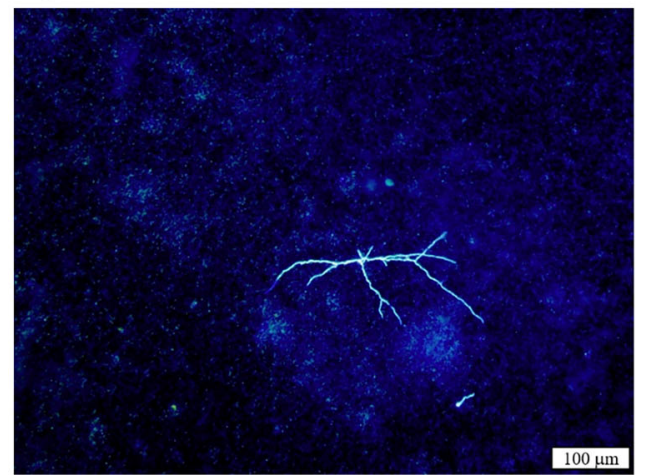

h)

Figure 5. Epifluorescence photomicrographs of inter-kingdom biofilm formation with $M$. oryzae on polystyrene over time with $\mathrm{CW}$ plus DAPI: (a) M. oryzae $+P$. expansum spores at $24 \mathrm{~h}$; (b) $M$. oryzae $+P$. expansum spores at $48 \mathrm{~h}$; (c) $M$. oryzae $+P$. expansum germinated spores at $24 \mathrm{~h}$; (d) $M$. oryzae $+P$. expansum germinated spores at $48 \mathrm{~h}$; (e) $M$. oryzae $+P$. brevicompactum spores at $24 \mathrm{~h}$; (f) M. oryzae $+P$. brevicompactum spores at $48 \mathrm{~h}$; (g) $M$. oryzae $+P$. brevicompactum germinated spores at $24 \mathrm{~h}$; $(\mathrm{h}) M$. ory$z a e+P$. brevicompactum germinated spores at $48 \mathrm{~h} . \times 200$ magnification; bar $=100 \mu \mathrm{m}$. 
Spores were used as the starting inoculum for biofilm formation as they comprise the primary source of viable propagules (Doggett 2000). However, hyphal fragments or other fungal propagules could also be used as they can be functionally equivalent to planktonic bacterial cells (Harding et al. 2009). The seeding spore density has also been reported to be an important factor in the development of biofilms of filamentous fungi with an optimal concentration of $10^{5}$ spores $\mathrm{ml}^{-1}$, which was why this concentration was used (Mowat et al. 2007; Simões et al. 2015). Higher spore concentrations result in poor germination of adhered spores while lower concentrations have a detrimental effect on hyphal density (Mowat et al. 2007).

Both spectrophotometric methods used in this study to quantify single-species and inter-kingdom biofilms have been used to study bacterial, yeast and filamentous fungal biofilms in microtitre plates (Goughenour et al. 2015; Simões et al. 2015; Dalecki et al. 2016; Xu et al. 2016). However, for the study of inter-kingdom biofilm formation their application is scarce. Methods aimed at analysing inter-kingdom biofilm formation between fungi and bacteria are yet to be standardized. In the present study, the dynamics of inter-kingdom biofilms on polystyrene surfaces over $72 \mathrm{~h}$ were assessed by biomass (CV) and metabolic activity (resazurin) measurements as well as by epifluorescence microscopy. CV staining is one of the main methods used for biofilm mass quantification. $\mathrm{CV}$ binds to negatively charged microorganisms as well as to the extracellular polymeric material. The absorbance values are directly proportional to the amount of biofilm biomass (Pantanella et al. 2013). However, this staining method has some limitations, including low reproducibility and not providing information on the number and viability of cells as it stains both living and dead, along with other components of the biofilm matrix (Simões et al. 2015). For this reason, resazurin was used as a complementary method to assess biofilm viability. Resazurin was chosen over other methods because, according to Simões et al. (2015), it was the most sensitive method tested and able to detect lower numbers of active cells. Resazurin is a non-fluorescent blue dye (watersoluble, stable, non-toxic, and permeable through cell membranes) that is reduced to the highly fluorescent pink coloured resorufin. This acts as an intermediate electron acceptor in the electron transport chain without interference by the normal transfer of electrons (Rampersad 2012). The resazurin assay is, however, very dependent on the growth phase and the age and thickness of the biofilm as these factors influence cell respiratory efficiency (Pantanella et al. 2013). In addition to the time of resazurin reduction being speciesand strain-related (Pantanella et al. 2013), method optimization (particularly incubation time) was required to measure the metabolic activity of interkingdom biofilms. Due to the spectrophotometric limitations and adding to the inter- and intra-variability of the experiments, a high standard deviation was observed in some cases.

Epifluorescence microscopy is commonly used to obtain rapid, inexpensive qualitative information on fungal cells (Ahmad and Khan 2012). CSLM has the advantage of allowing 3-D characterization of the biofilm structure, but it is much more expensive than fluorescence microscopy (Simões et al. 2015; Schlafer and Meyer 2017). Consequently, epifluorescence microscopy was used as a first approach to qualitatively analyse inter-kingdom biofilm development over time. CW staining allows the visualization of fungal cell walls because of its affinity for $\beta(1-3)$ and $\beta(1-4)$ polysaccharides in cellulose, carboxylated polysaccharides, and chitin (Siqueira et al. 2011, 2013; Simões et al. 2015). DAPI was selected due to its frequent use in microscopy as a nuclear counterstain to assist in morphological observations of the bacteria (Kormas et al. 2010; Siqueira et al. 2013). The excitation wavelength for CW and DAPI was the same and both signals were blue; however, they were distinctive in colour intensity and brightness in microscopic observations. In inter-kingdom biofilms, the stronger fluorescent signal coming from the fungal staining by CW made the acquisition of clear images showing both organisms more difficult. This happened especially when germinated spores were used as the starting inoculum due to the higher number of fungal hyphae (data not shown). Besides the difference in fluorescence intensity between microorganisms, to visualize bacteria it was usually necessary to focus on a different focal plane, usually lower, which made obtaining inter-kingdom biofilm images more difficult. Despite these drawbacks, the use of these stains allowed the discrimination of the microorganisms in inter-kingdom biofilms.

In the present study, fresh spores and germinated spores were used assuming that spores in different developmental stages might be present in DWDS and the latter provides an advantage in the metabolic state of the fungi. From the results it was observed that the fungal stage of development is important in the early stages of biofilm formation, as demonstrated by the increase in mass and specific metabolic activity at $24 \mathrm{~h}$ when using germinated spores $v s$ using fresh 
spores. Germinated spores, due to the presence of appendages, conferred an initial advantage in biofilm formation corresponding to phase II (adhesion) of the model for filamentous fungal biofilm formation proposed by Harding et al. (2009) and updated by Fernandes et al. (2019). In inter-kingdom biofilms, an increase in biomass when using germinated spores instead of fresh spores was also reported, but only for mature biofilms $(\geq 48 \mathrm{~h})$. The bacteria used in this study inhibited fungal sporulation and hyphal growth at $24 \mathrm{~h}$ independent of the fungal starting inoculum. This effect was most pronounced for the bacterium $A$. calcoaceticus. Similar results were obtained in studies of co-culture biofilm formation between A. fumigatus and Pseudomonas aeruginosa, where, for $24 \mathrm{~h}$, direct contact between the fungi and the bacterium as well as its supernatant resulted in an inhibition of fungal biofilm formation (Mowat et al. 2010). Co-culturing Rhizopus microsporus and Pseudomonas aeruginosa for $24 \mathrm{~h}$ also resulted in the inhibition of spore germination (Kousser et al. 2019). Additionally, Nogueira et al. (2019) demonstrated that co-culture experiments of Klebsiella pneumoniae with several Aspergillus species resulted in the inhibition of fungal spore germination and hyphal development. Aspergillus spores were also pre-germinated for $12 \mathrm{~h}$, followed by addition of $K$. pneumoniae strains, and revealed that the inhibitory effect of this bacterium on these fungal species is independent of the fungal growth stage (Nogueira et al. 2019). In the present study, a similar effect at $24 \mathrm{~h}$ was observed. However, using germinated spores as the starting material resulted in a less pronounced inhibition effect towards fungal growth in already mature biofilms $(48 \mathrm{~h})$, and at $72 \mathrm{~h}$ no inhibition was detected, as revealed by the biofilm mass increase. The removal of planktonic cells and the renewal of the medium might be the reason for this increase in fungal viability. Nogueira et al. (2019) also showed that Aspergillus species remain viable upon interaction with $K$. pneumoniae. The inhibitory effect at $24 \mathrm{~h}$ may be due to the direct competition for nutrients, the higher growth rate and metabolic activity of the bacteria, the production of metabolites that might inhibit fungal sporulation or a combination of all these factors (Mowat et al. 2010; Kousser et al. 2019; Nogueira et al. 2019). Nutritional competition between fungi and bacteria is well documented in other environments, for example in the rhizosphere where bacterial competition for nutrients can be an effective biocontrol mechanism against fungal pathogens (Elad and Baker 1985; Lemanceau et al. 1993). The occurrence of multiple interspecies interactions or even the simple production of a metabolite can also interfere with biofilm formation and development (Kives et al. 2005; Valle et al. 2006; Mowat et al. 2010).

The specific metabolic activity of inter-kingdom biofilms containing A. calcoaceticus, when compared with A. calcoaceticus single-species biofilms, was reduced in the presence of fungal spores and again the stage of spore germination was substantial in these changes. Inoculation with germinated spores caused the highest decrease in the metabolic activity of these biofilms. This seems to be connected with the ability of the fungi to grow and form a biofilm, as higher fungal biofilm mass is correlated with lower biofilm metabolic activity. However, regardless of the loss in specific metabolic activity, a high increase in A. calcoaceticus CFU was observed when inoculated alongside germinated spores of $P$. expansum. This indicates that, despite the effect on specific metabolic activity, a higher quantity of $P$. expansum mass helps this bacterium to increase in numbers. The fact that A. calcoaceticus has been reported to perform a bridging function, facilitating biofilm formation in DW as it coaggregates with other bacteria, may also have a role in this increase (Simões et al. 2008). Coaggregation provides advantages to microorganisms such as transfer of chemical signals, metabolic cooperation between different species and protection from adverse environmental conditions (Wimpenny and Colasanti 2004). This might be helped by the biotic support and protection that intertwined fungal hyphae confer to bacteria (Frey-Klett et al. 2011). The growth around fungal hyphae was visually confirmed by epifluorescence microscopy. In the presence of $M$. oryzae the correlation between biofilm mass and specific metabolic activity was not observed. The basal metabolic activity of each microorganism might also be a variable to take into consideration when performing inter-kingdom biofilm studies. In terms of CFU, differences were also seen when inoculated with spores in different developmental stages, as they decreased with fresh fungal spores but increased with germinated spores in early biofilms. In more mature biofilms, when inoculated with germinated spores of $P$. expansum, unlike with $A$. calcoaceticus, a decrease occurred. All these differences observed suggest variability in interspecific interactions that are microbially dependent. The results also suggest that $M$. oryzae might be more susceptible to $P$. expansum than $A$. calcoaceticus.

In conclusion, this study shows that the fungal spore development stage is important in the first $24 \mathrm{~h}$ 
of water fungal biofilm formation. With germinated spores a denser biofilm is established in the first $24 \mathrm{~h}$. It was observed that inter-kingdom biofilm formation between these specific filamentous fungi and bacteria isolated from DWDS is a possibility, as they can interact with each other and form mature biofilms. Nevertheless, inter-kingdom biofilm formation and development are microbially dependent, as shown by the variability in interspecific interactions. It was also shown that if both inter-kingdom microorganisms are inoculated at the same time, in the first $24 \mathrm{~h}$ of interaction, bacteria can, in fact, inhibit filamentous fungal spore germination and its development into a biofilm. However, with time and with the renewal of the medium, these fungi can begin to germinate and develop into mature biofilms. This is particularly interesting because if the possibility of biofilm formation is provided for the fungi, or if there is a chance of existing a pre-established fungal biofilm, consequently, an advantage may also be given to opportunistic bacteria to replicate and proliferate in inter-kingdom biofilms inside DWDS.

\section{Disclosure statement}

No potential conflict of interest was reported by the author(s).

\section{Funding}

Tiago B. Afonso acknowledges the grant provided by the Portuguese Foundation for Science and Technology (FCT) under grant no. PD/BD/128033/2016. This study was also supported by FCT under the scope of the strategic funding of UID/BIO/04469/2019 unit and BioTecNorte operation (NORTE-01-0145-FEDER-000004) funded by the European Regional Development Fund under the scope of Norte2020 - Programa Operacional Regional do Norte. Fundação para a Ciência e a Tecnologia.

\section{References}

Ahmad I, Khan M. 2012. Microscopy in mycological research with especial reference to ultrastructure's and biofilm studies In: Méndez-Vilas A, editor. Current microscopy contributions to advances in science and technology. Spain: Formatex Research Centre; p. 646-659.

Anaissie EJ, Stratton SL, Dignani MC, Lee C, Summerbell RC, Rex JH, Monson TP, Walsh TJ. 2003. Pathogenic molds (including Aspergillus species) in hospital water distribution systems: a 3-year prospective study and clinical implications for patients with hematologic malignancies. Blood. 101:2542-2546. doi:10.1182/blood-2002-02-0530

Åslund P. 1984. Skin irritations cause by moulds (in Swedish). Vår Föda. 36:327-336.
Berry D, Xi C, Raskin L. 2006. Microbial ecology of drinking water distribution systems. Curr Opin Biotechnol. 17: 297-302. doi:10.1016/j.copbio.2006.05.007

Borges A, Saavedra MJ, Simões M. 2012. The activity of ferulic and gallic acids in biofilm prevention and control of pathogenic bacteria. Biofouling. 28:755-767. doi:10. 1080/08927014.2012.706751

Bryers JD, Ratner BD. 2004. Bioinspired implant materials befuddle bacteria. ASM News. 70:232-237.

Characklis WG, Marshall KC. 1990. Biofilms: a basis for an interdisciplinary approach. In: W. G. Characklis, \& K. C. Marshall, editors. Biofilms. New York: John Wiley \& Sons, Inc.

Dalecki AG, Crawford CL, Wolschendorf F. 2016. Targeting biofilm associated Staphylococcus aureus using resazurin based drug susceptibility assay. J Vis Exp. 111: e53925.

Doggett MS. 2000. Characterization of fungal biofilms within a municipal water distribution system. Appl Environ Microbiol. 66:1249-1251. doi:10.1128/AEM.66.3. 1249-1251.2000

Douterelo I, Boxall JB, Deines P, Sekar R, Fish KE, Biggs CA. 2014. Methodological approaches for studying the microbial ecology of drinking water distribution systems. Water Res. 65:134-156. doi:10.1016/j.watres.2014.07.008

Douterelo I, Calero-Preciado C, Soria-Carrasco V, Boxall JB. 2018. Whole metagenome sequencing of chlorinated drinking water distribution systems. Environ Sci Water Res Technol. 4:2080-2091. doi:10.1039/C8EW00395E

Douterelo I, Jackson M, Solomon C, Boxall JB. 2016. Microbial analysis of in situ biofilm formation in drinking water distribution systems: implications for monitoring and control of drinking water quality. Appl Microbiol Biotechnol. 100:3301-3311. doi:10.1007/ s00253-015-7155-3

Elad Y, Baker R. 1985. The role of competition for iron and carbon in suppression of chlamydospore germination of Fusarium spp. by Pseudomonas spp. Phytopathology. 75: 1053-1059. doi:10.1094/Phyto-75-1053

Feazel LM, Baumgartner LK, Peterson KL, Frank DN, Harris JK, Pace NR. 2009. Opportunistic pathogens enriched in showerhead biofilms. Proc Natl Acad Sci USA. 106:16393-16399. doi:10.1073/pnas.0908446106

Fernandes S, Simões LC, Lima N, Simões M. 2019. Adhesion of filamentous fungi isolated from drinking water under different process conditions. Water Res. 164: 114951. doi:10.1016/j.watres.2019.114951

Frey-Klett P, Burlinson P, Deveau A, Barret M, Tarkka M, Sarniguet A. 2011. Bacterial-fungal interactions: hyphens between agricultural, clinical, environmental, and food microbiologists. Microbiol Mol Biol Rev. 75:583-609. doi:10.1128/MMBR.00020-11

Gomes IB, Simões M, Simões LC. 2014. An overview on the reactors to study drinking water biofilms. Water Res. 62:63-87. doi:10.1016/j.watres.2014.05.039

Gonçalves AB, Paterson RM, Lima N. 2006. Survey and significance of filamentous fungi from tap water. Int J Hyg Environ Health. 209:257-264. doi:10.1016/j.ijheh.2005.12.001

González-Ramírez AI, Ramírez-Granillo A, Medina-Canales MG, Rodríguez-Tovar AV, Martínez-Rivera MA. 2016. Analysis and description of the stages of Aspergillus fumigatus biofilm formation using scanning electron 
microscopy. BMC Microbiol. 16:243. doi:10.1186/s12866016-0859-4

Goughenour KD, Balada-Llasat JM, Rappleye CA. 2015. Quantitative microplate-based growth assay for determination of antifungal susceptibility of Histoplasma capsulatum yeasts. J Clin Microbiol. 53:3286-3295. doi:10.1128/ JCM.00795-15

Gutierrez-Correa M, Villena GK. 2003. Surface adhesion fermentation: a new fermentation category (Fermentacion por adhesion a superficies: una nueva categoria fermentativa). Rev Peru Biol. 10:113-124.

Hageskal G, Gaustad P, Heier BT, Skaar I. 2007. Occurrence of moulds in drinking water. J Appl Microbiol. 102: 774-780. doi:10.1111/j.1365-2672.2006.03119.x

Harding MW, Marques LLR, Howard RJ, Olson ME. 2009. Can filamentous fungi form biofilms?. Trends Microbiol. 17:475-480. doi:10.1016/j.tim.2009.08.007

Jones J. 1994. Fungal adhesion. Mycol Res. 98:961-981. doi: 10.1016/S0953-7562(09)80421-8

Kastman EK, Kamelamela N, Norville JW, Cosetta CM, Dutton RJ, Wolfe BE. 2016. Biotic interactions shape the ecological distributions of Staphylococcus species. MBio. $7: 1-13$.

Kives J, Guadarrama D, Orgaz B, Rivera-Sen A, Vazquez J, SanJose C. 2005. Interactions in biofilms of Lactococcus lactis spp. cremoris and Pseudomonas fluorescens cultured in cold UHT milk. J Dairy Sci. 88:4165-4171. doi:10. 3168/jds.S0022-0302(05)73102-7

Kormas KA, Neofitou C, Pachiadaki M, Koufostathi E. 2010. Changes of the bacterial assemblages throughout an urban drinking water distribution system. Environ Monit Assess. 165:27-38. doi:10.1007/s10661-009-0924-7

Kousser C, Clark C, Sherrington S, Voelz K, Hall RA. 2019. Pseudomonas aeruginosa inhibits Rhizopus microsporus germination through sequestration of free environmental iron. Sci Rep. 9:5714. doi:10.1038/s41598-019-42175-0

Lahaye É, Renaux JJ, Le Tilly V, Sire O. 2016. Evolution of a fungal ecosystem in a water distribution system to a positive bacterial biofilm subsequent to a treatment using essential oils. Comptes Rendus Chimie. 19:505-510. doi: 10.1016/j.crci.2015.09.014

Lemanceau P, Bakker PA, De Kogel WJ, Alabouvette C, Schippers B. 1993. Antagonistic effect of nonpathogenic Fusarium oxysporum Fo47 and pseudobactin 358 upon pathogenic Fusarium oxysporum f. sp. dianthi. Appl Environ Microbiol. 59:74-82.

Li X, Wang W, Hu C, Yang M, Hu H, Niu J. 2015. Characteristics of biofilms and iron corrosion scales with ground and surface waters in drinking water distribution systems. Corros Sci. 90:331-339. doi:10.1016/j.corsci. 2014.10.028

Metzger WJ, Patterson R, Fink J, Semerdjian R, Roberts M. 1976. Sauna-takers disease. Hypersensitivity due to contaminated water in a home sauna. JAMA. 236: 2209-2211. doi:10.1001/jama.1976.03270200047032

Momba MNB, Kfir R, Venter SN, Loete T. 2000. An overview of biofilm formation in distribution systems and its impact on the deterioration of water quality. Water SA. 26:59-66.

Mowat E, Butcher J, Lang S, Williams C, Ramage G. 2007. Development of a simple model for studying the effects of antifungal agents on multicellular communities of
Aspergillus fumigatus. J Med Microbiol. 56:1205-1212. doi:10.1099/jmm.0.47247-0

Mowat E, Rajendran R, Williams C, McCulloch E, Jones B, Lang S, Ramage G. 2010. Pseudomonas aeruginosa and their small diffusible extracellular molecules inhibit Aspergillus fumigatus biofilm formation. FEMS Microbiol Lett. 313:96-102. doi:10.1111/j.1574-6968.2010.02130.x

Muller E, Drewello U, Drewello R, Weismann R, Wuertz S. 2001. In situ analysis of biofilms on historic window glass using confocal laser scanning microscopy. J Cult Herit. 2:31-42. doi:10.1016/S1296-2074(01)01106-2

Nogueira M, Pereira L, Jenull S, Kuchler K, Lion T. 2019. Klebsiella pneumoniae prevents spore germination and hyphal development of Aspergillus species. Sci Rep. 9:218. doi:10.1038/s41598-018-36524-8

Pantanella F, Valenti P, Natalizi T, Passeri D, Berlutti F. 2013. Analytical techniques to study microbial biofilm on abiotic surfaces: pros and cons of the main techniques currently in use. Ann Ig. 25:31-42.

Paterson RR, Lima N. 2005. Fungal contamination of drinking water In: Lehr J, Keeley J, Lehr J, Kingery TB III, editors. Water encyclopedia: the water quality and resource development. New York (NY): Wiley; p. 1-7.

Paterson RR, Lima N. 2010. Toxicology of mycotoxins. EXS. 100:31-63.

Ramage G, Rajendran R, Gutierrez-Correa M, Jones B, Williams C. 2011. Aspergillus biofilms: clinical and industrial significance. FEMS Microbiol Lett. 324:89-97. doi: 10.1111/j.1574-6968.2011.02381.x

Rampersad SN. 2012. Multiple applications of alamar blue as an indicator of metabolic function and cellular health in cell viability bioassays. Sensors. 12:12347-12360. doi: $10.3390 / \mathrm{s} 120912347$

Sav H, Rafati H, Oz Y, Dalyan-Cilo B, Ener B, Mohammadi F, Ilkit M, Van Diepeningen AD, Seyedmousavi S. 2018. Biofilm formation and resistance to fungicides in clinically relevant members of the fungal genus Fusarium. JoF. 4:16. doi:10.3390/jof 4010016

Schlafer S, Meyer RL. 2017. Confocal microscopy imaging of the biofilm matrix. J Microbiol Methods. 138:50-59. doi:10.1016/j.mimet.2016.03.002

Seneviratne G, Zavahir JS, Bandara W, Weerasekara M. 2008. Fungal-bacterial biofilms: their development for novel biotechnological applications. World J Microbiol Biotechnol. 24:739-743. doi:10.1007/s11274-007-9539-8

Simões LC, Simões M. 2013. Biofilms in drinking water: problems and solutions. RSC Adv. 3:2520-2533. doi:10. 1039/C2RA22243D

Simões LC, Simões M, Lima N. 2015. Kinetics of biofilm formation by drinking water isolated Penicillium expansum. Biofouling. 31:349-362. doi:10.1080/08927014.2015. 1042873

Simões LC, Simões M, Vieira MJ. 2007a. Biofilm interactions between distinct bacterial genera isolated from drinking water. Appl Environ Microbiol. 73:6192-6200. doi:10.1128/AEM.00837-07

Simões LC, Simões M, Oliveira R, Vieira MJ. 2007b. Potential of the adhesion of bacteria isolated from drinking water to materials. J Basic Microbiol. 47:174-183. doi:10.1002/jobm.200610224

Simões LC, Simões M, Vieira MJ. 2008. Intergeneric coaggregation among drinking water bacteria: evidence of a 
role for Acinetobacter calcoaceticus as a bridging bacterium. Appl Environ Microbiol. 74:1259-1263. doi:10.1128/ AEM.01747-07

Simões LC, Simões M, Vieira MJ. 2010. Influence of the diversity of bacterial isolates from drinking water on resistance of biofilms to disinfection. Appl Environ Microbiol. 76:6673-6679. doi:10.1128/AEM.00872-10

Siqueira VM, Oliveira HM, Santos C, Paterson R, Gusmão N, Lima N. 2011. Filamentous fungi in drinking water, particularly in relation to biofilm formation. Int J Environ Res Public Health. 8:456-469. doi:10.3390/ijerph8020456

Siqueira VM, Oliveira HMB, Santos C, Paterson RRM, Gusmão NB, Lima N. 2013. Biofilms from a Brazilian water distribution system include filamentous fungi. Can J Microbiol. 59:183-188. doi:10.1139/cjm-2012-0529

Stepanović S, Vuković D, Dakić I, Savić B, Švabić-Vlahović M. 2000. A modified microtiter-plate test for quantification of staphylococcal biofilm formation. J Microbiol Methods. 40:175-179. doi:10.1016/S0167-7012(00)00122-6

Valle J, Re DS, Henry N, Fontaine T, Balestrino D, LatourLambert P, Ghigo JM. 2006. Broad-spectrum biofilm inhibition by a secreted bacterial polysaccharide. Proc Natl Acad Sci U S A. 103:12558-12563. doi:10.1073/pnas. 0605399103

Wang H, Zhu Y, Hu C. 2017. Impacts of bacteria and corrosion on removal of natural organic matter and disinfection byproducts in different drinking water distribution systems. Int Biodeterior Biodegradation. 117: 52-59. doi:10.1016/j.ibiod.2016.11.023

Wimpenny J, Colasanti R. 2004. A simple automaton model for coaggregation. Biofilms. 1:369-375. doi:10.1017/ S1479050505001584

Xu Z, Liang Y, Lin S, Chen D, Li B, Li L, Deng Y. 2016. Crystal violet and XTT assays on Staphylococcus aureus biofilm quantification. Curr Microbiol. 73:474-482. doi: 10.1007/s00284-016-1081-1

Zhou X, Zhang K, Zhang T, Li C, Mao X. 2017. An ignored and potential source of taste and odor (T\&O) issuesbiofilms in drinking water distribution system (DWDS). Appl Microbiol Biotechnol. 101:3537-3550. doi:10.1007/ s00253-017-8223-7 